\title{
The Study of Solidarity and the Social Theory of Alain Touraine
}

\author{
Luke Martell and Neil Stammers \\ Published in Jon Clark and Marco Diani eds, Alain Touraine, Falmer, 1996.
}

This chapter is a critical assessment of the study of Solidarity carried out by Alain Touraine and his research team in 1981 and first published in French in 1982 and in English in 1983.

The book (Touraine et al. 1983) has drawn a mixed response from critics. Some have tended to regard the study as providing rich, detailed and important insights into the early history of the movement (Bauman 1985; Kennedy 1991; Law 1984; terry 1984; Watson 1984). Others - especially those whose principle concern has been to evaluate Touraine's wider social theory - have seen Solidarity as manifesting the contradictions, inconsistency and opacity said to be characteristic of his work (Goldfarb 1989; Scott 1991). What is curious, given both the historical significance of Solidarity and the controversy surrounding Touraine's work, is that there has been no previous attempt - in English at least - to make the Solidarity study itself the central object of investigation.

We will begin by locating the study and outlining its central findings. Then we will analyze the extent to which the study fulfils its internal objectives and how it relates to concepts and categories found in Touraine's work. We will argue that Solidarity is a comprehensive, illuminating and important piece of work and that some criticisms have been misdirected. There are, though, problems in the study caused by instances of both continuity and discontinuity between the Solidarity study and Touraine's wider social theory. In particular there is an unresolved tension between the findings in respect of the evolutionary development of Solidarity and Touraine's understanding of a social movement; and, as a result of a reliance on preconceived categories in the sociological intervention, Touraine et al. fail to account properly for the potential development of neo-liberal and reactionary nationalist currents in Solidarity.

\section{Locating the study}

The period from the mid-1970s to the mid-1980s was when Touraine was most intensively involved with the study of social movements and produced his most detailed theoretical elaboration of social movements and social change in The Voice and the Eye (1981). First published in French in 1978 as La Voix et le Regard. This text sought to explain his action-centred theory of social movements and his method of sociological intervention for studying and facilitating their development. It also set out a proposed framework of research, the explicit purpose of which was to study the transition from industrial society to programmed society and to discover the social movement which, in programmed 
society, would occupy the central position held by the workers' movement in industrial society (Touraine, 1981:24). This program of research included studies of French movements including the student movement (1978), the anti-nuclear movement (1980), the Occitanist movement (1981) and the workers' movement (1984).

So the study of Solidarity is situated at the very heart of this period of Touraine's intellectual work. Yet, while there are significant references to communist societies in The Voice and the Eye, the original research plan did not envisage any study of oppositional movements in Eastern Europe (1981: 23-4). Touraine was then pessimistic about the potential for social movement action in communist societies. There he argued that, while working-class struggles and embryonic social movements develop, defensive resistance 'can never develop into a true social movement because the state completely crushes society' (1981: 130).

Nevertheless, the emergence of Solidarity presented Touraine with his first, and arguably an unparalleled, opportunity both to study and to intervene with a movement which might both qualify according to his definition of a social movement as a '. . . class actor struggling for the social control of historicity against his class adversary in a concrete community' (1981: 77) and which was set in the wider context of an 'historical struggle' (1981: 102, 117 and 125).

The specified aims of the study are:

'to understand the nature, internal workings and evolution of Solidarity (1983: 2); to help establish the belief that men and women are not subject to historical laws and material necessity, that they produce their own history through their cultural creations and social struggles' (1983: 5).

According to Touraine et al., the research 'followed very closely' the method of sociological intervention developed by Touraine for the study of social movements. This method 'seeks to define the meaning which the actors themselves attribute to their action.' But while actors' self-analysis is important, it is the task of the researcher to identify 'with the highest possible meaning of that struggle, which is nothing other than the social movement', to enable groups of activists to 'isolate, among the various meanings of its action, the one which challenges the central core of the society' (1983: 7-8). To this end, sociological intervention has two phases: in the first the researchers help groups of movement activists towards self-analysis; and in the second - called 'conversion' - the group reanalyzes its own practices and those of its movement on the basis of hypotheses introduced by the researchers. The researchers' hypotheses are judged satisfactory if they are accepted by the group and help that group to return to action. 
The study of Solidarity was completed between April and November 1981, and was mainly conducted by establishing groups of between eight and eleven militants, 'as diverse as possible in composition' who were all grassroots activists in Solidarity. Three groups were formed in the spring of 1981 in Gdansk, Katowice and Warsaw and three further groups formed in the autumn of 1981 in Szczecin, Lodz and Wroclaw. The study explains the procedures adopted as follows:

'The groups first met interlocutors from the party, industry, the Church, the press and the political opposition, as well as leaders of Solidarity; they then went back over these meetings and, with the help of the researchers, formulated a first analysis of their action. Then the researchers submitted to them their own hypotheses and examined the way in which these were received - accepted, rejected or modified - in the course of long joint working sessions. (1983: 9)

The first three groups also met in pairs in Warsaw, and these groups had further meetings with the researchers in the autumn of 1981 (1983: 114, 124, 131) before the latter started working with the groups formed in the autumn. A joint Franco-Polish research team of four or five people was involved with each group. The group research was supplemented with shorter talks and interviews, and two members of the research team attended the Solidarity Congress in Gdansk in September 1981. Because of the imposition of martial law, the research findings were written up by the French researchers alone.

\section{Central Findings}

Examining the period from the emergence of Solidarity in August 1980 to the imposition of martial law in December 1981, the study offers a series of detailed and interlinked findings. Here we try to set them out as clearly as possible.

\section{A 'Total Social Movement'}

Solidarity was found to be primarily a trade union and a workers' movement, but it was more than this. It was, say Touraine et al., a total social movement. It was 'total' in the sense that it encompassed and incorporated national and democratic aspirations as well as those of class, and that - initially at least - these were fused and inseparable. This broad ideological composition as a total social movement can be explained, the authors suggest, by the way it developed in opposition to the totalizing ambitions of the Polish party state regime and that regime's relation to the Soviet Union. They point out that in communist societies the party state was simultaneously a political agent and the owner and employer in the economic realm, while at the same time subject to external Soviet domination. In other words, the party state comprises and represents domination in the political, economic, and national spheres. Oppositional movements in communist regimes thus come to develop a wide 'total' form because these 
forms and levels of domination cannot be separated. This stands in contrast to advanced Western capitalist countries where political power appears to be separated from economic relations and there are no overt 'imperial' relations constraining national sovereignty.

\section{The 'Liberation of Society'}

Touraine et al. argue that Solidarity went beyond its trade union and social movement dimensions. While it did not aspire to be a political party holding power itself, it did aspire to freeing society from the totalitarian party state. The authors argue that, while there were those in Solidarity who saw it as a social movement concerned with workers' rights, others saw it as a movement for the liberation of society with political, as well as social, objectives.

While consistent in the use of the phrase 'liberation of society', Solidarity is variously described as 'a movement' (1983: 58, 175, 177), 'an agent' $(96,173)$ and 'an action' (135) for the liberation of society. Given the centrality of 'movement', 'agent' and 'action' to Touraine's work on social movements and social change, this degree of imprecision is unfortunate, especially since no explicit attempt is made to relate this aspect of Solidarity to any of the categories offered in the Voice and the Eye.

It is, nevertheless, clear that this aspect of Solidarity is the more 'political' side that more prepared to question and challenge the legitimacy of the existing order. To the extent that this involves rejecting the existing cultural stakes, this side of Solidarity does not appear to fit Touraine's definition of a social movement; something which always struggles with an adversary for control of shared cultural stakes.

\section{Defensive and Counter-Offensive Orientations}

As well as distinguishing between social movement and movement for the liberation of society, the authors distinguish between defensive, communitybased orientations and counter-offensive, reforming and institutional orientations in Solidarity. In respect of the liberation of society side of Solidarity, this distinction appears to be drawn from The Voice and the Eye, where Touraine (1981: 129-30) argues that struggles against communist regimes can develop in either of two different directions. On the one hand intellectuals may struggle for democratization; this strand tends to be strongest at moments of less repression. On the other hand there can be populist dissident defence, most likely at moments when domination expands. 
Figure 9.1 Aspects of Solidarity

\begin{tabular}{|c|c|c|}
\hline & Social Movement & Liberation of Society \\
\hline Defensive Action & Workers' control & Defensive Populism \\
\hline $\begin{array}{c}\text { Counter-Offensive } \\
\text { action }\end{array}$ & 'Spirit of Gdansk' & Political Democracy \\
\hline
\end{tabular}

Source: Touraine et al. (1983): 174

Breaking down Solidarity into these strands allows the authors to offer a representation of the movement as a whole as shown in Figure 9.1. Workers' control involves workers' defensiveness or retreat from the existing regime. It is focused on trade union action and the enterprise and oriented away from political action. The spirit of Gdansk involves a more positive attempt to obtain legal and political reforms for workers. It is still worker-oriented but more political and institutional in its strategic orientation. Defensive populism is more defensive than 'Gdansk' and more populist than workers' control. It involves defence of the people against the authorities and often takes a nationalist form. It is, say Touraine et al., incompatible with the 'sprit of Gdansk'. Political democracy involves the positive democratization of society as a whole. Like Gdansk, this is positive rather than defensive in its orientation, although its concerns are for society as a whole rather than just workers' or trade union concerns. Touraine et al. identify intellectuals as the agents of this last tendency.

\section{Light and Shade}

Throughout Solidarity, the authors display a positive valuation of the more reforming, institutional strands of the movement and a distaste for the defensive and populist strands. The former are characterized as comprising the 'light' side of the movement and the latter its 'shade'. Touraine et al. have a developmental scheme in which they outline the development of the movement through various stages. They identify the earlier days with the light, and the later defensive populist withdrawal, in response to the crisis and the threatened crackdown, with the shade. 'Light' and 'shade' in Solidarity seem to break down as shown in Figure 9.2. 
Figure 9.2. 'Light' and 'Shade' in Solidarity

\begin{tabular}{|c|c|c|}
\hline & Light & Shade \\
\hline Orientation & $\begin{array}{l}\text { Reconstruction of Society } \\
\text { Democratization }\end{array}$ & $\begin{array}{l}\text { Defensive } \\
\text { Retreatist }\end{array}$ \\
\hline Agent & $\begin{array}{l}\text { Working Class } \\
\text { Intellectuals }\end{array}$ & Rank and File \\
\hline Timescale & $\begin{array}{c}\text { Gdansk } \\
\text { August } 1980 \\
\end{array}$ & Summer 1981 onwards \\
\hline Class & $\begin{array}{l}\text { Defence of Workers' } \\
\text { interests }\end{array}$ & $\begin{array}{l}\text { Populist defence of weak } \\
\text { against strong }\end{array}$ \\
\hline Nation & $\begin{array}{l}\text { Affirmation of National } \\
\text { identity }\end{array}$ & Aggressive nationalism \\
\hline Democracy & Defence of Freedoms & $\begin{array}{c}\text { Populist appeal to save } \\
\text { the nation }\end{array}$ \\
\hline
\end{tabular}

\section{Regressive Development: From SI to SIII}

The authors argue that Solidarity went through three phases in its development from the time of its emergence in August 1980 to the imposition of martial law in December 1981 (1983: Ch. 4). Solidarity I was focused on obtaining free trade unions in Poland. Solidarity II called for self-management in enterprises and the economy in general. Solidarity III aimed at democratization not only in the economy but also in political institutions, most obviously through the call for free elections at the Solidarity Congress in September 1981. At the same time, in a second dimension of Solidarity III, the movement - under pressure from economic crisis, the threat of Soviet intervention and a Party crackdown - moved from a counter-offensive political orientation towards a defensive populism. Solidarity was characterized by a double evolution towards political action on one hand and defensiveness, prompted by crisis, on the other.

This can be related back to the two sides of Solidarity as a social movement and a movement for the liberation of society. At one point Touraine et al. identify SI as a social movement, SII as a social movement plus a movement for the liberation of civil society and SIII as more directly political (1983: 173). In a somewhat different formulation they also argue that, in the first few months of its existence, the two elements of 'social movement' and 'action for the liberation of society' were highly integrated (1983: 83) and that this integration was maintained throughout the period of SIII. Indeed they argue that the different versions of the theme of self-management were powerful integrating factors bringing together 'Solidarity the social movement' and 'Solidarity the agent of social liberation' (1983: 96). But, by SIII, the movement was appearing more as a movement for the liberation of society than a trade union or social movement, and it was coming close to fracturing as the nationalist component tended to break away and enter into conflict with the democratic element. 
The authors found marked tendencies towards aggressive nationalism, antisemitism and fundamentalism in the groups they worked with in the autumn of 1981, and it is these tendencies which are associated with the 'defensive populism' which became the predominant tone by the autumn of 1981 . They ask whether the aspect of the movement's action which is most strongly reinforced: 'is the one which combines a political orientation with a defensive, populist, aggressively rank and file tone, while the one that suffers most is the one uniting a truly working class movement with the desire for the general democratisation of society' (1983: 156).

\section{A Self-Limiting Movement}

An important feature of Solidarity was that it consciously adhered to a self-limiting strategy (1983: Ch. 3). It was widely perceived that the leading role of the party should not be challenged or Poland's international treaty obligations questioned because overstepping such limits would have brought about Soviet military intervention. As one of the militants from the Warsaw group put it: 'As a nation we realise we are caught between a political system and certain geographical facts, and that we have to exist within that framework. The problem is to recognise those limits and to know how far we can go' (1983: 65).

One of the essential questions which then arose during the research (1983: 23) was the extent to which Solidarity remained a self-limiting movement even in its later phase, as it became more overtly political and as it became less a social movement and more a movement for the liberation of society. Touraine et al. maintain that in this phase too, and even immediately prior to the imposition of martial law when confrontation was seen to be coming, the movement nevertheless retained its commitment to self-limitation because it '. . . refused to constitute itself as an actor seeking to take power' (1983: 181); 'it never sought to take over the state' (1983: 183).

\section{New Social Movement Characteristics of Solidarity}

The idea of self-limitation is often closely associated with the concept of 'new social movements'. The extent to which the authors describe Solidarity in terms which Touraine (1981) himself had previously ascribed to new social movements is striking. Directly connected to the idea of self-limitation is also the nonrevolutionary and non-violent character of the movement, and we have already seen that an important element of Solidarity's commitment was to selfmanagement. In The Voice and the Eye Touraine had depicted new social movements as struggling against technocracy and had argued that communist regimes could develop towards a state technocratic form (1981: 124-5). This characterization could potentially fit the struggle of Solidarity against the Polish party state in 1980-81. 
It should be stressed that at no stage in Solidarity do the authors use the term 'new social movements', and Poland is consistently described as an industrial society. Nevertheless, Solidarity is clearly found to have characteristics elsewhere seen by Touraine to be those of a new social movement.

\section{Analyzing Solidarity}

\section{The Objectives of the Study}

As noted above, Touraine et al. set out to 'understand the nature, the internal workings and the evolution of Solidarity' (1983: 2). In particular, their aim was to understand the self-definitions of actors in Solidarity, using the method of sociological intervention, and to show the importance of Solidarity as an active agent in its own evolution and not just as a product of external determinant forces.

The authors certainly come up with complex and detailed responses to this agenda. Solidarity is defined in terms of the combination of themes of class, nation and democracy. The authors distinguish between the complex diversity of Solidarity as a workers' movement, total social movement, movement for the liberation of society, and between the defensive and offensive emphases it took in these different manifestations. They outline a scheme to explain Solidarity's evolution. Additionally external and internal influences on the development of Solidarity, such as the church and Soviet-imposed constraints, are discussed, as are Solidarity's self-limiting tactics. In all these respects the study is one which gives a rich picture of Solidarity's nature, internal ideological meanings and the phases through which it evolved. The study also outlines in detail the selfdefinitions and meanings developed by actors and gives emphasis and credence to them.

There are some problems, however, in terms of the objectives the study set itself. First of all, categories such as class, nation and democracy and the analysis of directions of resistance to communist regimes were first developed in The Voice and the Eye and then apparently reworked into the analysis of Solidarity. Sociological intervention, involving the introduction of hypotheses and wider contextual explanations (the 'T -presence' or 'stakes') by researchers, was the vessel for this. As we will argue below, the combination of themes continued from earlier work, and their introduction through sociological intervention may have led to an attribution of meanings to Solidarity which were partly predetermined.

Furthermore, it may have facilitated the downplaying or exclusion of meanings, such as nationalism and neo-liberalism, which were not conducive to the aim of sociological intervention to assist with the development of a progressive social movement, or which were not included in the predetermined threefold classification of class, nation, democracy. 
A second problem is that, while the study is strong on identifying actors' own selfdefinitions, Solidarity pays little attention to organizational and political dynamics within the movement (see also Hannigan, 1985). There is some attention to dissatisfaction with the leadership's negotiating strategies and internal democracy. But, mostly, issues to do with political strategy, mobilization and internal relations between different parts of the movement, all things which resource mobilization theorists would highlight, are left untouched. In other words, Touraine et al. develop the ideological side of their promised analysis of the internal dynamics of Solidarity; but they leave the organizational side relatively untouched.

\section{Relation to Touraine's Wider Social Theory}

There are striking and major continuities and discontinuities between Touraine's then contemporary theoretical framework as outlined in The Voice and the Eye and his research team's study of Solidarity. Trying to get to grips with these and assessing their significance are frustrated by the lack of cross-referencing from Solidarity back to The Voice and the Eye and the lack of any attempt to locate the former in terms of any wider framework. This may be partly why some commentators have relied on 'macrolevel' critiques of Touraine's work when discussing Solidarity and have thus missed some of its most interesting aspects.

Here we will point to the important discontinuities before seeking to explain how, nevertheless, there are important and useful continuities in terms of the analysis of collective action. This provides a platform for the next section where we will explain how these continuities and discontinuities cause problems for Touraine et al.'s analysis.

The concept of 'total social movement', clearly central to the analysis of Solidarity, does not appear in The Voice and the Eye. Touraine had used the term before, in The Self-Production of Society. But there movements were seen as 'total' not in the sense that they incorporate the three broad ideological components of class, nation and democracy, but because they were said to have the capacity to straddle the three hierarchical action systems (the organizational, the institutional and the level of historicity) which are key to Touraine's understanding of society and social relations in both The Self-Production of Society and The Voice and the Eye. The need to reformulate 'total social movement' arose because in The Voice and the Eye Touraine had not considered it possible that social movements could develop fully in communist societies.

There are also marked breaks and absences in Solidarity where ideas developed in The Voice and the Eye would have been relevant and pertinent. Since the idea of a fundamental transition to post-industrial or programmed society was central to Touraine's work, it is strange that there is no mention of the extent to which Poland was thought to be involved in that transition. This is all the more 
surprising since there are indications in The Voice and the Eye that Touraine saw communist regimes as being part of that transition, and especially because Solidarity was found to have many of the characteristics he ascribes to new social movements. Elsewhere he sees new social movements as typical of programmed societies, and the question of why a workers' movement in an industrial society should exhibit their characteristics is not discussed in Solidarity.

A central preoccupation running through The Voice and the Eye is the distinction between synchronic and diachronic analysis. Synchrony is associated with cuts into time, where function is the main organizing principle and class the dominating agent. Diachrony is associated with change over time. Development is its main organizing principle with the state the main agent. Touraine argues that in concrete 'historical struggles' synchrony and diachrony are combined (1981: 125-6). Yet this central preoccupation of Touraine's theory of collective action and social change does not appear at all in Solidarity despite the fact that this book analyzes a concrete social struggle which fulfils Touraine's criteria of a 'historical struggle' at the meeting of the diachronic and synchronic.

There are, nevertheless, certain forms of explanation carried through from The Voice and the Eye to Solidarity, such as those relating to counter-offensive and defensive forms of action; the light and shade; the reformulation of the categories of class, nation and modernization; the analysis of forms of resistance to communist regimes; the conception of the IOT triangles defining collective action; and the distinction between social movements and other forms of movement and collective behaviour.

But in the Solidarity study the theoretical or explanatory framework remains implicit and inferred. It is simply not discussed. We have, therefore, in Figure 9.3 tried to provide a schematic representation to demonstrate how categories and explanations in Solidarity can be 'mapped' onto central categories occurring in The Voice and the Eye at the level of historicity and to illustrate the purpose of sociological intervention. We assume some familiarity on the part of the reader with Touraine's overall theoretical framework and the synchronic/diachronic dichotomy. However, some points require elaboration. First, as noted above, Touraine makes it clear that the synchronic-diachronic dimensions are never truly separate as the schematic representation might suggest. In reality they interact. Second, different forms of collective behaviour are associated with the different poles on the action-crisis, order-change axes. In terms of crisis and change, collective behaviour is largely reactive and defensive. While opposition to order is regarded positively, it is only where collective behaviour takes the form of action by a self-conscious actor at the level of historicity that Touraine uses the term 'social movement'. In other words, although Touraine sees social movement as a crucial category (especially as he sees society becoming increasingly able to produce itself), in terms of forms of collective behaviour it is a restricted category. 
Figure 9.3 Relation of Categories in the Voice and the Eye and Solidarity at the Level of Historicity and the Purpose of Sociological Intervention

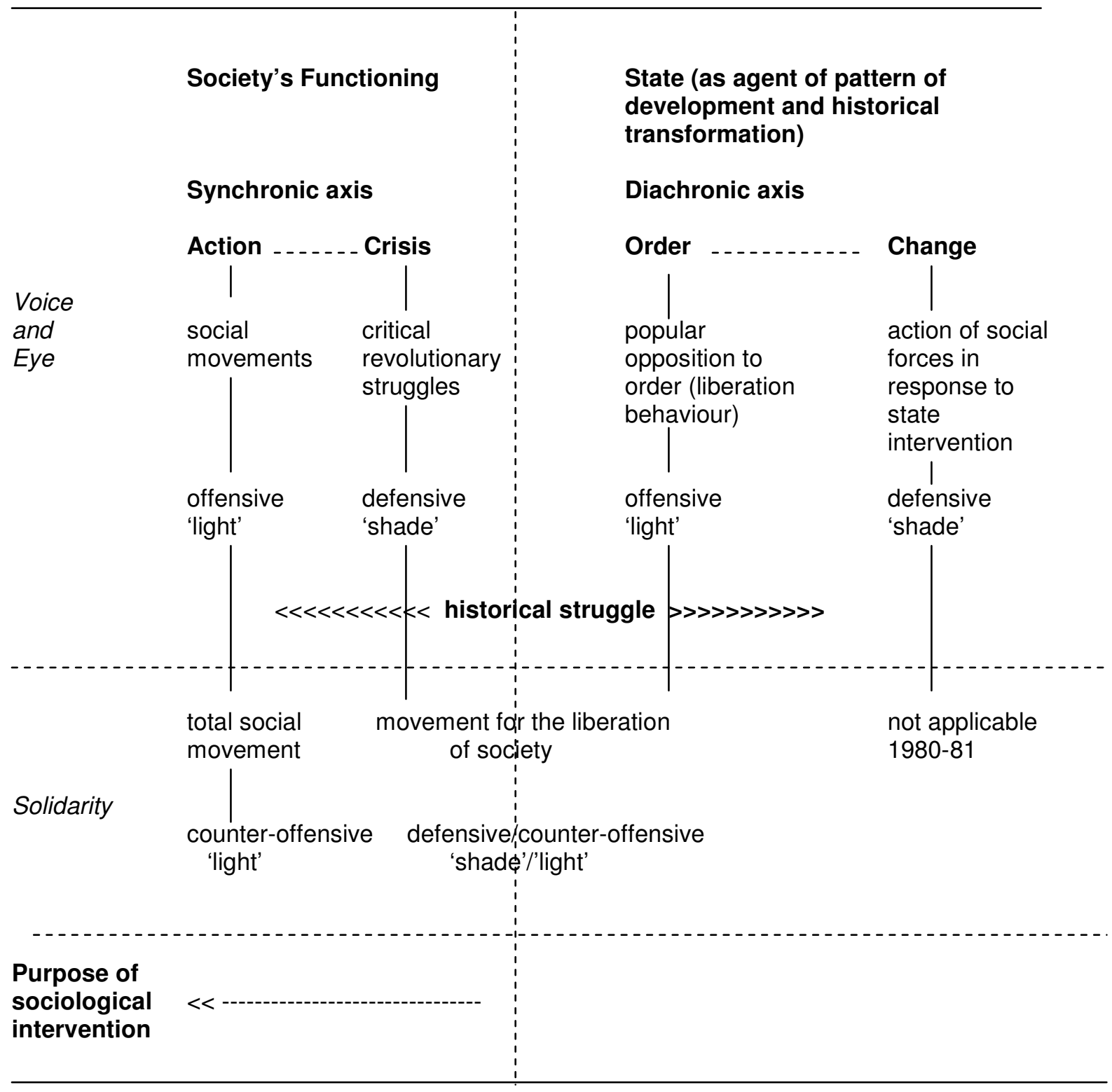

Let us move now to the significance of Figure 9.3 for the study of Solidarity. The importance of the distinction between the social movement aspect of Solidarity and that aspect which the authors relate to the liberation of society should now be apparent. Solidarity as a total social movement is a social movement proper in Touraine's sense, while that aspect of the movement which sought the liberation of society appears to be a combination of popular opposition to the maintenance of the existing order but also a critical revolutionary struggle as a direct response to crisis. The importance of the developmental evolution of Solidarity identified by Touraine et al. can now be seen in terms of Solidarity combining a social 
movement proper with popular opposition to the maintenance of the existing order, but gradually these aspects being submerged into a reactive critical revolutionary struggle. Put in this context, Touraine et al.'s optimistic evaluation of Solidarity as a whole seems hard to square with his assessment of the various forms of collective action in The Voice and the Eye.

Furthermore, this continuity between The Voice and the Eye and Solidarity may not all be benign. We will go on to discuss how both continuity and discontinuity between Solidarity and Touraine's wider work may cause problems for the former.

\section{Assessing Solidarity}

If we have portrayed the parallels between categories in The Voice and the Eye and the analysis of Solidarity correctly, then it would appear that there is a much closer relationship between the two than has been previously identified. By focusing on other issues, earlier critics have missed these connections. The question which then arises is whether the empirical findings in Solidarity confirm the usefulness of these categories from The Voice and the Eye or alternatively, whether they were artificially imposed on the movement by the researchers.

We have already expressed our view that the study of Solidarity provides a rich and detailed account of the movement and of the self-understandings of Solidarity activists. The concepts and categories drawn from Touraine's earlier work seem to us to have been used as effective tools in the analysis of complex phenomena, indicating that aspects of Touraine's theoretical work have the capacity to provide important insights into various forms of collective behaviour in different cultural, social and political settings. To this extent we share Bauman's view that Touraine et al. demonstrate the 'fertility of theory' in Solidarity (Bauman 1983: 597).

However, we also feel that the continuities and discontinuities between the study of Solidarity and Touraine's wider social theory, combined with the committed nature of sociological interventionism, cause problems in Solidarity. Discontinuity causes problems on the issue of forms of movement appropriate to industrial and post-industrial society, while in terms of continuity, sociological intervention and the use of categories from The Voice and the Eye lead Touraine et al. to potentially underestimate the importance of neo-liberal and nationalist currents in Solidarity. Below we consider these in more detail.

\section{Agency and a New Social Movement in an Industrial Society?}

As noted above, Touraine's historical theory of post-industrial or programmed society, as set out in The Voice and the Eye, does not appear in Solidarity. Yet it would seem to be especially relevant to Solidarity and its omission causes ambiguities. 
A major criticism made of Touraine's application of concepts and categories to Solidarity is that it contradicts a central claim of his theory of social movements and historical change. Critics argue that in The Voice and the Eye Touraine claims that reflexive self-productive agency and new social movements are exclusive to postindustrial society; yet in Solidarity the authors demonstrate the role of reflexive agency and new social movement type activity in a society explicitly considered industrial. In other words it is argued that the findings in respect of Solidarity contradict and undermine the argument in The Voice and the Eye.

Thus Scott argues that 'those countries in which the "new politics" and new social movements have had most impact are in many ways conventional industrial societies' (1991: 37) and that: 'This is particularly problematic in Touraine's analysis of Solidarity. . . . Poland can hardly be considered a "post-industrial" society, yet Touraine ascribes to it many of the characteristics of the new social movement of Solidarity' [sic] (1991: 43). Similarly, Goldfarb (1989: 127) argues that in the study of Solidarity the researchers get actors to practise reflexive selfanalysis which, he claims, contradicts Touraine's view in The Voice and the Eye that such self-reflexivity is only possible in post-industrial society.

In our view these criticisms are misplaced because Touraine neither locates reflexive self-productive agency solely in post-industrial societies $(1981: 40,59)$, nor does he argue that the characteristics of new social movements are to be found exclusively there. Indeed, on this latter point he makes it clear in The Voice and the Eye that the purpose of his research program is to study the transition from industrial to post-industrial society and the complex intervening phenomena of that period (1981: 9). In The Voice and the Eye he explicitly allows for the possibility of new social movement action between industrial and post-industrial society (1981: 9-11).

So, far from undermining an exclusive confinement of agency and new social movement characteristics to post-industrial society, their discovery of a workers' movement in an industrial society could support the contention that the buds of such phenomena will be found in the transitional period prior to post-industrial society being established. In other words, the authors' discovery of such processes in Solidarity potentially confirms rather than undermines Touraine's expectations in The Voice and the Eye.

Touraine has also often been accused of falling back into a structuralism he claims to have left behind. Scott (1991), for example, claims that, despite holding to an agency-centred explanation in his social movement theory, Touraine is determinist and teleological in his periodizing of history into sequential stages. We have some doubts about whether such a criticism is tenable in relation to his work generally. But in Solidarity it cannot apply because Solidarity does not incorporate Touraine's theory of history. The analysis is of the development of a movement during the period 1980-81. It operates at the level of a cut into history, 
not situated in terms of a periodization of societal stages. In Solidarity Touraine shows a movement attempting to define its own development, limiting and advancing itself in terms of its own judgment about external constraints and opportunities and not just reacting to external economic, social, political or cultural determinants. It is, in other words, a largely agency-centred explanation untainted by any possible residues of historical determinism.

Yet, while on these issues we would defend Touraine against the criticism of inconsistency and contradiction, the problem is largely self-generated because of the failure to work through the relation between The Voice and the Eye and Solidarity. As in other respects, the authors fail to draw the links between the study of Solidarity and Touraine's social theory. Despite the fact that in The Voice and the Eye Touraine has made a big issue of different societal types, distinguishing industrial from postindustrial society and associating each with different forms of reflexivity and movement activity, he and his co-authors fail to revive this issue in a context where they are analyzing a movement with 'new' characteristics in the apparently anomalous context of an industrial society.

\section{Sociological Intervention and the Study of Solidarity}

Touraine's method of sociological intervention has been much discussed and criticized (Cohen, 1983: 216; Hannigan, 1985: 447; Kivisto, 1984: 362-5; Scott, 1991: 40-1). Here we consider specific problems with the method which may have adversely affected the study of Solidarity. Our principal concern is that in Solidarity the authors combine the reworking of categories from The Voice and the Eye with sociological intervention, a method which stresses a role for researchers' categories in furthering the goal of developing a progressive social movement. This, we feel, leads Touraine to bring in categories to define Solidarity which were predetermined. This leads to the underestimation of important dimensions not encompassed by the prior theoretical framework and not compatible with the intervention project.

There are three levels of problem relating to the choice and representativeness of the groups studied. First, no information is provided as to how the individual activists who comprised the groups were chosen. Second, despite the authors' claim to have established groups in cities which were the main centres of Solidarity's activities, at least one critic has disputed this and claimed that the choice of location was arbitrary (Watson, 1984). Third, the meanings developed by six groups of activists in six locations can only tentatively be made the basis for generalizations about Solidarity as a whole.

Another problem more central to our concerns is the effect of intervention on the groups being studied. There were no control groups, so we do not know whether similar meanings were being developed elsewhere where there was no sociological intervention. However, we would argue that one consequence of sociological intervention is that it affects meanings developed by group members. 
The method is intended to do precisely this, but we would argue that it is both sociologically and politically problematic for it to do so.

Even if the aim of the study were only to understand the meanings generated by the groups themselves, these meanings would not simply be those of the actors, but of actors interacting in a changed situation with researchers. Furthermore, such a project would be limited in its aims and possible achievements. Yet the authors do make generalizations about the movement as a whole on the basis of the group interventions. In our view this is problematic. Touraine et al. can only claim confidently to be able to say things about the groups with which they were involved themselves, something which limits the explanatory power of the study.

In many respects Touraine's aim is a committed one: to raise the level of activists' self-understandings to the higher level of social movement activity. Yet the sociological deficiency just discussed also becomes a strategic deficiency. This is because findings are generated which, once generalized, may not accurately grasp the character of the movement as a whole. On the basis of a misreading of the character of the movement generally, miscalculations in social action may result, especially if sociological intervention leads to an overoptimistic view of the development of the movement of the sort which, we argue below, Touraine et al. developed.

\section{Class, Nation, Democracy. . . and Neo-Liberalism?}

There is a specific area in which sociological intervention may have skewed the findings of the study. 'Class', 'nation' and 'democracy' are three of the key meanings which were introduced to the groups by the researchers and which are subsequently identified in Solidarity as defining the movement. However, it is clear in The Voice and the Eye that Touraine had already developed a threecategory framework with which to explain collective behaviour outside the central capitalist countries. National-popular regimes in the Third World and communist regimes are analyzed as performing functions of national liberation, economic modernization and class action (1981: 126-9). These three categories, reworked, appear again in Solidarity, where the movement is defined as a class movement (in defence of working-class interests) and in terms of nation (Polish nationalism) and modernization (democratization) (1983: 185).

Two interpretations could be put on the reappearance of these three categories in Solidarity. One is that Solidarity was characterized in terms of predefined general categories created by the researchers rather than meanings defined by actors themselves. If this were so, it casts doubt on whether class, nation and democracy fully grasp actors' self-definitions, as the authors claim. On the other hand, it could be that the application of class, nation and democracy in the Solidarity study results from an intervention in which researchers' perceptive hypotheses were introduced and accepted by actors because of the way they successfully illuminated and advanced their self- understandings. It is, we feel, 
significant that in the autumn of 1981 these hypotheses were vigorously challenged by some Solidarity activists (1983: 164).

Another worry we have is less about the way in which class, nation and democracy may have defined actors' self-interpretations and more about what it may have left out. In terms of Solidarity and Poland's development after 1981, two main negative developments which have occurred are downplayed as serious likelihoods in the authors' mostly optimistic and supportive conclusions in respect of Solidarity. One is the rise of a negative side of nationalism. This is discussed as a possibility but downplayed. We shall return to this issue shortly. The other is the potential for the rise of neo-liberal ideas (see Ost, 1989).

Solidarity frequently deals with reform of the economy and the control of enterprises (1983: 92-8, 109-11, 116, 119-22). Touraine et al. more than once argue that Polish workers are not interested in capitalism (1983: 50), yet they do mention two leading figures in Solidarity who advanced neo-liberal proposals for the economy (1983: 147-8 and 151). So the authors were not unconscious of neo-liberalism as an issue. Yet there is no suggestion from the presentation of their findings that they tried to see if there were a basis for the development of neo-liberalism by raising it with activists in the interventions. There are three possible reasons why they failed to do so.

First, Touraine et al. see capitalism and socialism as less radically distinct than other theorists do. They argue, for instance, that both belong to industrial society and are based on the same class relation between workforce and managers (1983: 41). One result of perceiving the two systems as comparable, however, is that this may have prevented the authors from seeing the appeal neo-liberalism might have to Polish people as an alternative to state socialism. In other words, a prior theoretical disposition may have led them to discount the potential importance of neo-liberal ideas.

Second, Touraine et al. rightly see Solidarity's acceptance of the leading role of the party and state in Poland as a product of its self-limiting response to, among other things, the external Soviet threat. We now know that when, under Gorbachev, this threat was removed, a restraint on the development of capitalism was lifted. But before these changes occurred, Touraine's identification of external constraints and Solidarity's self-limiting response to them may have been one understandable reason why he did not consider the potential rise of neo-liberal ideas as significant.

Third, Touraine et al. may not have introduced neo-liberalism in the interventions because of their focus on identifying the possible development of progressive social movements. The consideration of neo-liberalism may not have seemed relevant to such a project. If so, we would argue that failing to analyze possible support for neo-liberal ideas undermined progressive social action by excluding 
from consideration possible negative future developments which social actors need to analyze and account for.

This argument may also explain the downplaying of the role of negative forms of nationalism which came to be so prominent in Poland and Central and Eastern Europe later in the 1980s and 1990s. It is to this issue that we turn next.

\section{Nationalism, the Light and the Shade}

Touraine's approach to collective action emphasizes its double-sided nature, and the distinction between light and shade in Solidarity (represented schematically in Figure 9.2 above) is drawn from The Voice and the Eye. In their positive - light manifestations, collective action tends to be affirmative, reconstructive, offensive and politically-oriented. The negative face - the shade - is defensive, populist and retreatist.

The predominant perspective on nationalism in Solidarity is a positive one. It is prefigured in a discussion in The Voice and the Eye on the role of national movements in opposition to communist state domination. 'A class movement cannot develop outside the centre of the capitalist system', he argues, 'unless it takes national interest in hand' (1981: 133). 'An appeal to the nation is also a call to the popular classes. . . in struggling against domination how can one turn for support to anything but that which is most traditional, most deep-rooted' (1981: 134). He specifically argues here that nationalism is necessary to popular mobilization against state domination in communist regimes.

In Solidarity national consciousness is seen as a source of mobilization against the imposition of power by an external state, the Soviet Union. National liberation is inextricably linked to Solidarity's trade unionism and struggle for democracy because both of these are seen to require struggle against foreign exploitation and domination (1983: Ch. 2).

Yet Touraine et al. are also clearly aware of the negative potentialities of nationalism. As we have shown, they argue that as the political and economic situation worsened, nationalism in Solidarity shifted from affirmation of identity to an aggressive nationalism. This aggressive nationalism was more defensive than proactive and was opposed to the political and democratizing approach of opposition intellectuals (1983: 48-9 and Chs 6 and 7).

The authors ask, 'is the effect of the dramatic situation of 1981 not to extend the area of the movement which is in shadow at the expense of the lighter areas?' (1983: 156). At this point Touraine et al. certainly see the rise of the shade in the form of anti-semitism, aggressive nationalism, populism and mistrust of political action as leading to disintegration within the movement. Yet, while aware of this dangerous dark side of nationalism, the authors minimize and dismiss the potential of this danger to grow rather than diminish, without offering any clear 
grounds for doing so. For example, writing of the period after the imposition of marital law, they argue:

'There is a danger that the political and military dictatorship at present ruling Poland may succeed in forcing the popular movement to retreat to a traditionalist and religious defence of community values which up to now has been the position of only a very small minority. It is however a relatively minor danger. (1983: 185)

This is an optimism which has been shown to be seriously misplaced by subsequent events in Poland and Europe more generally. Yet to have admitted otherwise would have crucially undermined one of the central arguments of the study - that throughout the period August 1980-December 1981 Solidarity remained a unified, integrated movement, and was 'a light. . . [which] . . .shines on us all' (1983: 5).

\section{Conclusion: Beyond Social Movements; The Sociologist Quits the Field?}

Touraine's recent work continues his conceptualization of light and shade but now puts more emphasis on the place of the shade as if responding with hindsight to that which had been brushed aside in Solidarity. We will conclude by assessing this apparent shift.

In his sociology of social movements, sociological intervention is not simply a research method. It is also the method through which Touraine attempted to put into practice his project of facilitating the light of social movements in contrast to the shade of other forms of collective behaviour. As outlined in Figure 9.3 above, it is only on the synchronic axis and at the level of historicity (rather than at the institutional or organizational levels) that a social movement comes into being when a self conscious class actor is able to act and define its action both in terms of its adversary and the shared cultural stakes. This necessarily precludes a vast variety of forms of collective behaviour which occur on the institutional or organizational levels, or on the diachronic axis, or the 'crisis' pole of the synchronic axis. Touraine's task was to help activists identify with the highest meaning of the struggle, that is more towards social movement action. So, despite the fact that Touraine has long recognized that light and shade necessarily exist side by side in contemporary collective behaviour, his project had been essentially rationalist. It had been rationalist insofar as Touraine clearly believed that his theoretical framework - including his theory of social movements and collective behaviour - was more 'truthful' than possible alternative explanations and that his practical project had been to attempt to shift collective action towards the light of that 'truth'.

Yet in a reply to a critique of his work published in 1991 Touraine notes that 'social movements are less and less "progressive" and more and more critical', and that '[t]he study of contemporary social movements leads us to abandon a 
unified, rationalist or progessist [sic] view of modernity. . . .' He says that he has become 'more and more interested in the study of what we call anti-social movements, like terrorism. . . or populist nationalism which we observe in Poland within and against Solidarnosc.' Furthermore, he now regards his period of study of social movements as an intermediary one (Touraine, 1991).

In his most recent major work, Critique de la Modernité (1992), while he retains many of his earlier theoretical categories in some form, he appears to make a clear shift in his thinking around his notions of 'light' and 'shade'. In what could be seen as a disavowal of his earlier program of research and intervention with social movements, he argues that the illusion of rationalism was to believe that 'light must chase away the shadows' (Touraine, 1992: 348). The task he sees now is finding a combination of these which will guarantee, rather than threaten, the continued existence of the subject.

We are not able to say whether it was the study of Solidarity which began to sow the seeds of doubt which have led to the re orientation of Touraine's work. What is clear is that it is precisely those issues and tensions which were downplayed and glossed over in Solidarity which also make it clear that the optimism shared by radical activists and theorists of social movements in the 1970s and 1980s was sorely misplaced. In the context of the imposition of martial law and the suppression of Solidarity, Touraine et al.'s positive and supportive evaluation of the movement was understandable. Indeed, opposition movements in Eastern Europe were generally supported uncritically by activists and theorists in the West until after the party state regimes fell in 1989.

Touraine's work has often been heavily criticized, and not without justification. Yet in the case of Solidarity some of these criticisms are unwarranted - often caricaturing, rather than representing, Touraine's social theory. Despite our own criticisms, we feel that Solidarity will remain one of the most important studies of the early history of the movement because it succeeds in representing the views of the Solidarity activists who participated with richness and depth.

We have argued that the application of preconceived categories, combined with a desire and a commitment on the part of the authors to present Solidarity in a positive light, resulted in a failure to take account of the potential for neo-liberal and reactionary nationalist currents to develop. Yet it is to the credit of Touraine and his research team that the detailed nature of their findings allows us to apply the benefit of hindsight.

\section{Acknowledgements}

We are grateful to Anna Fielder for her translation of Critique de la Modernité and to William Outhwaite and Paul Taggart for their valuable comments on this chapter. 


\section{Bibliography}

Bauman, Z. (1983) Review of A. Touraine et al., 'Anti-Nuclear Protest' and 'Solidarity', Sociology, 17, 4, November, 596-8.

Cohen, J.L. (1983) Class and Civil Society. London, Martin Robertson.

Goldfarb, J. (1989) Beyond Glasnost: the post-totalitarian mind. Chicago, Chicago University Press.

Hannigan, J.A. (1985) 'Alain Touraine, Manuel Castells and Social Movement Theory; a critical appraisal', The Sociological Quarterly, 26, 4, 435-54.

Kennedy, M. (1991) Professionals, Power and Solidarity in Poland. Cambridge, Cambridge University Press.

Kivisto, P. (1984) 'Contemporary Social Movements in Advanced Industrial Societies and Sociological Intervention: an appraisal of Alain Touraine's "Pratique"', Acta Sociologica, 27, 4, 355-66.

Law, D. (1984) Review of A. Touraine et al. 'Solidarity', Sociological Review, 32, 2, 429-31.

Ost, D. (1979) 'The Transformation of Solidarity', Telos, 79, Spring.

Scott, A. (1991) 'Action. Movement and Intervention: Reflections on the Sociology of Alain Touraine', Canadian Review of Sociology and Anthropology, $28,1,30-45$.

Terry, S.M. (1984) Review of A. Touraine et al. 'Solidarity', Political Science Quarterly, 99, 3, 574-5.

Touraine, A. (1977) The Self-Production of Society. Chicago, University of Chicago Press.

Touraine, A. (1981) The Voice and the Eye: an analysis of social movements. Cambridge, Cambridge University Press.

Touraine, A. (1991) 'Commentary on Dieter Rucht's Critique', in D. Rucht ed. Research on Social Movements: the state of the art in Western Europe and the USA. Boulder, Westview Press, 385-91.

Touraine, A. (1992) Critique de la Modernité, Paris, Fayard. 
Touraine, A., Dubet, F., Hegedus, Z., and Wieviorka, M. (1978) Lutte Étudiante. Paris, Seuil.

Touraine, A., Hegedus, Z., Dubet, F., and Wieviorka, M. (1980) La Prophétie anti-nucléaire. Paris, Seuil. Published in English in 1983 by Cambridge University Press as Anti-Nuclear Protest.

Touraine, A., Dubet, F., Hegedus, Z., and Wieviorka, M., (1981) Le Pays contre l'État. Paris, Seuil.

Touraine, A., Dubet, F., Wieviorka, M. and Strzelecki, J. (1983) Solidarity: Poland 1980-81. Cambridge, Cambridge University Press.

Touraine, A., Wieviorka, M., and Dubet, F., (1984) Le Mouvement Ouvrier. Paris, Seuil. Published in English in 1987 by Cambridge University Press as The Workers' Movement.

Watson, M. (1984) Review of A. Touraine et al. 'Solidarity', Soviet Studies, 36, 3, 467-9. 